\title{
Front Matter: Volume 9657
}

, "Front Matter: Volume 9657," Proc. SPIE 9657, Industrial Laser Applications Symposium (ILAS 2015), 965701 (1 July 2015); doi: 10.1117/12.2203631

EPIE Event: Industrial Laser Applications Symposium 2015, 2015, Kenilworth, SPIE. United Kingdom 


\title{
PROCEEDINGS OF SPIE
}

\section{Industrial Laser Applications Symposium (ILAS 2015)}

\author{
Mike Green \\ Editor
}

17-18 March 2015

Kenilworth, United Kingdom

\author{
Organised by \\ Association of Industrial Laser Users \\ Sponsored by \\ BOFA International (United Kingdom) \\ II-VI (United States) \\ IPG Photonics (United Kingdom) \\ Laser Trader (United Kingdom) \\ TRUMPF (United Kingdom)
}

\section{Cooperating Organizations}

Confederation of British Metalforming • Club Laser et Procédés • European Photonics Industry Consortium • Institute of Engineering and Technology • Institute of Physics • Laser Institute of America - Manufacturing Technologies Association • South of England Photonics Network • Knowledge Transfer Network • Engineering and Physical Sciences Research Council

Published by

SPIE

\section{Volume 9657}


The papers included in this volume were part of the technical conference cited on the cover and title page. Papers were selected and subject to review by the editors and conference program committee. Some conference presentations may not be available for publication. The papers published in these proceedings reflect the work and thoughts of the authors and are published herein as submitted. The publisher is not responsible for the validity of the information or for any outcomes resulting from reliance thereon.

Please use the following format to cite material from this book:

Author(s), "Title of Paper," in Industrial Laser Applications Symposium: ILAS 2015, edited by Mike Green, Proceedings of SPIE Vol. 9657 (SPIE, Bellingham, WA, 2015) Article CID Number.

ISSN: 0277-786X

ISBN: 9781628418705

Published by

SPIE

P.O. Box 10, Bellingham, Washington 98227-0010 USA

Telephone +1 3606763290 (Pacific Time) · Fax +1 3606471445

SPIE.org

Copyright (C) 2015, Society of Photo-Optical Instrumentation Engineers.

Copying of material in this book for internal or personal use, or for the internal or personal use of specific clients, beyond the fair use provisions granted by the U.S. Copyright Law is authorized by SPIE subject to payment of copying fees. The Transactional Reporting Service base fee for this volume is $\$ 18.00$ per article (or portion thereof), which should be paid directly to the Copyright Clearance Center (CCC), 222 Rosewood Drive, Danvers, MA 01923. Payment may also be made electronically through CCC Online at copyright.com. Other copying for republication, resale, advertising or promotion, or any form of systematic or multiple reproduction of any material in this book is prohibited except with permission in writing from the publisher. The CCC fee code is 0277-786X/15/\$18.00.

Printed in the United States of America.

Publication of record for individual papers is online in the SPIE Digital Library.

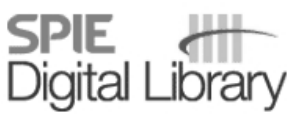

SPIEDigitalLibrary.org

Paper Numbering: Proceedings of SPIE follow an e-First publication model, with papers published first online and then in print. Papers are published as they are submitted and meet publication criteria. A unique citation identifier (CID) number is assigned to each article at the time of the first publication. Utilization of CIDs allows articles to be fully citable as soon as they are published online, and connects the same identifier to all online, print, and electronic versions of the publication. SPIE uses a six-digit CID article numbering system in which:

- The first four digits correspond to the SPIE volume number.

- The last two digits indicate publication order within the volume using a Base 36 numbering system employing both numerals and letters. These two-number sets start with 00, 01, 02, 03, 04, $05,06,07,08,09,0 A, 0 B \ldots 0 Z$, followed by 10-1Z, 20-2Z, etc.

The CID Number appears on each page of the manuscript. The complete citation is used on the first page, and an abbreviated version on subsequent pages. 


\title{
Contents
}

\author{
$\checkmark \quad$ Authors \\ vii Conference Committee \\ ix Introduction \\ xi Sponsors and Supporting Organisations
}

\section{ADDITIVE PROCESSES}

965702 Nano-hardness and microstructure of selective laser melted AlSi10Mg scan tracks [9657-105]

965703 Laser cladding of nickel-based alloy coatings on copper substrates [9657-15]

\section{CUITING AND DRILLING}

965704 Laser drilling of via micro-holes in single-crystal semiconductor substrates using a 1070nm fibre laser with millisecond pulse widths [9657-13]

965705 Advances in drilling with fiber lasers [9657-91]

965706 Definition of fine cutting features for laser fusion cutting of stainless steel [9657-49]

965707 Fast and intuitive programming of adaptive laser cutting of lace enabled by machine vision [9657-95]

965708 Laser remote cutting of metallic materials: opportunities and limitations [9657-9]

\section{FUME EXTRACTION}

965709 Legal requirements and guidelines for the control of harmful laser generated particles, vapours and gases [9657-55]

\section{LASHARE EUROPEAN COLLABORATIVE PROJECT}

9657 OA Laser processing system for stitching structured patterns on large 3D parts [9657-20]

9657 OB Cognitive high speed defect detection and classification in MWIR images of laser welding [9657-40]

9657 0C Laser cutting metallic plates using a 2kW direct diode laser source [9657-54] 
9657 OD Pulsed UV and ultrafast laser micromachining of surface structures [9657-76]

9657 OE The effect of laser pulse duration and beam shape on the selective removal of novel thin film layers for flexible electronic devices [9657-8]

9657 OF SMI: a new method to allow low cost, high resolution micro-machining using UV solid state lasers [9657-75]

\section{SURFACE MARKING AND FUNCTIONALITY}

9657 OG Laser surface texturing of cast iron steel: dramatic edge burr reduction and high speed process optimisation for industrial production using DPSS picosecond lasers [9657-33]

$9657 \mathrm{OH}$ Laser induced micro plasma processing of polymer substrates for biomedical implant applications [9657-59]

9657 0l Black anneal marking with pulsed fiber lasers [9657-47]

9657 0J Nanosecond laser texturing of aluminium for control of wettability [9657-58]

9657 OK Development in laser peening of advanced ceramics [9657-81]

$9657 \mathrm{OL}$ Laser surface treatment of polyamide and NiTi alloy and the effects on mesenchymal stem cell response [9657-79]

\section{WELDING}

$96570 \mathrm{M}$ Laser welding of copper and aluminium battery interconnections [9657-19]

9657 ON Numerical simulation and experimental investigation of laser dissimilar welding of carbon steel and austenitic stainless steel [9657-16] 


\title{
Authors
}

Numbers in the index correspond to the last two digits of the six-digit citation identifier (CID) article numbering system used in Proceedings of SPIE. The first four digits reflect the volume number. Base 36 numbering is employed for the last two digits and indicates the order of articles within the volume. Numbers start with 00, 01, 02, 03, 04, 05, 06, 07, 08, 09, 0A, 0B...0Z, followed by 10-1Z, 20-2Z, etc.

\author{
Aboulkhair, Nesma T., 23 \\ Antonopoulos, G., 2F \\ Apte, Paul, 2E \\ Ashcroft, Ian, 23 \\ Assunção, E. G., 2D \\ Balu, Prabu, 24 \\ Baumann, Robert, 29 \\ Beyer, Eckhard, 29 \\ Blackburn, Jon, 2D, 2N \\ Bruneel, David, $2 \mathrm{H}$ \\ Cano Zuriguel, Rafael, 2B \\ Castro, Gemma, 2C \\ Chan, C., $2 \mathrm{M}$ \\ Coupland, J., $2 O$ \\ De Bono, Paola, 2N \\ Deng, Justin, 24 \\ Everitt, Nicola M., 23 \\ Fallahi Sichani, E., 2D \\ French, Paul W., 2I, 2K \\ García-Díaz, Antón, 28, 2 C \\ Harrison, P., 27, 2J \\ Hauschild, D., 2D \\ Herwig, Patrick, 29 \\ Hodson, Jonathan R., 25 \\ Horsey, John, 2A \\ Hussain, I., 2M \\ Irving, M., 2 | \\ Kapnopoulos, C., $2 \mathrm{~F}$ \\ Karnakis, Dimitris, 2F, 2H \\ Kearsley, Andrew, $2 \mathrm{H}$ \\ Khan, A. H., 2D \\ Kong, C. Y., 2D \\ Lapido, Yago L., 2C \\ Laskarakis, A., 2F \\ Lawrence, Jonathan, 2L, 2M \\ Logothetidis, S., 2F \\ Maclean, Jessica O., 25 \\ Man, H. C., $2 \mathrm{M}$ \\ Marimuthu, S., 20 \\ Maskery, Ian, 23 \\ Meinschien, J., 2D \\ Mekeridis, E., $2 F$ \\ Milne, David, $2 G$ \\ Moorhouse, C., $2 \mathrm{~F}$ \\ Murphy, M., 21 \\ Murphy, T., 2J \\ Myles, David, 2G \\ Naeem, Mohammed, 26 \\ Nekovie Esfahani, M. R., 20
}

\author{
Norman, S., 27, 2J \\ Powell, J., 2D \\ Rea, Edward, 24 \\ Rodriguez-Araújo, Jorge, 2C \\ Romero, Pablo, 2C \\ Rosowski, Adam P., 2I, 2K \\ Rumsby, Phil, 2G \\ Saludes Rodil, Sergio, 2B \\ Seebach, J., 27 \\ Sharp, Martin C., 2I, 2K \\ Shukla, Pratik, 2L, 2M \\ Siebert, René, 29 \\ Smith, Graham C., 2L, 2M \\ Souto-López, Álvaro, 28 \\ Sykes, Neil, 2E \\ Tuck, Chris, 23 \\ Vaamonde, lago, 28 \\ Vergara, Germán, 2C \\ Vidal, Félix, 2C \\ Voisey, K. T., 25 \\ Waugh, David G., 2L, 2M \\ Wetzig, Andreas, 29
}


Proc. of SPIE Vol. $9657965701-6$

Downloaded From: https://www.spiedigitallibrary.org/conference-proceedings-of-spie on 26 Apr 2023 Terms of Use: https://www.spiedigitallibrary.org/terms-of-use 


\title{
Conference Committee
}

\author{
Organising Committee
}

Neil Main, Chair, Micrometric (United Kingdom)

Mike Green, Secretary, Association of Industrial Laser Users (United Kingdom)

Ric Allott, STFC Rutherford Appleton Laboratory (United Kingdom)

Malcolm Gower, Imperial College London (United Kingdom)

Paul Hilton, TWI (United Kingdom)

Martin Sharp, Liverpool John Moores University (United Kingdom)

Stewart Williams, Cranfield University (United Kingdom)

Technical Programme Committee

Simon Andrews, Fraunhofer Centre for Applied Photonics

(United Kingdom)

Jon Blackburn, TWI (United Kingdom)

Adam Clare, University of Nottingham (United Kingdom)

Paul Goodwin, Laser Cladding Technology (United Kingdom)

Duncan Hand, Heriot-Watt University (United Kingdom)

Roger Hardacre, Advanced Laser Technology (United Kingdom)

Paul Harrison, SPI Lasers (United Kingdom)

Nick Longfield, Rolls Royce (United Kingdom)

Martin Sharp, Liverpool John Moores University (United Kingdom)

Stan Wilford, IPG Photonics (United Kingdom)

Reviewing Committee

Chris Allen, TWI (United Kingdom)

Simon Andrews, Fraunhofer Centre for Applied Photonics (United Kingdom)

Jon Blackburn, TWI (United Kingdom)

Paul Goodwin, Laser Cladding Technology (United Kingdom)

Malcolm Gower, Imperial College London (United Kingdom)

Mike Green, Pro Laser (United Kingdom)

Duncan Hand, Heriot-Watt University (United Kingdom)

Jonathan Lawrence, University of Chester (United Kingdom)

John Powell, Laser Expertise (United Kingdom)

Martin Sharp, Liverpool John Moores University (United Kingdom)

Stewart Williams, Cranfield University (United Kingdom) 
Marketing

Gareth Rowles, II-VI (United Kingdom)

Stan Wilford, IPG Photonics (United Kingdom)

Administration

Liz Guntert, Association of Industrial Laser Users

(United Kingdom)

Catherine Rose, Association of Industrial Laser Users

(United Kingdom) 


\section{Introduction}

In March 2015, AILU was proud to hold the 4th Industrial Laser Applications Symposium (ILAS) in Warwickshire, United Kingdom. The biennial event explored wide-ranging aspects of laser materials processing and provided an interface between industry and academia. It attracted well over 200 participants.

This 2-day symposium offered over 90 presentations in parallel sessions, including plenary and keynote contributions. This book of Symposium Proceedings contains a selection of peer-reviewed manuscripts from ILAS 2015, documenting the wide range of topics covered including: additive manufacturing; cladding and hardening; macro cutting and drilling; micro and nano processing; precision fabrication; sources, beam delivery and system integration; surface marking and functionality; welding and a review of the EU-funded LASHARE project.

We would like to thank all our sponsors, supporting organizations and particularly SPIE for their assistance in producing this publication.

Mike Green ILAS Secretary 
Proc. of SPIE Vol. 9657 965701-10

Downloaded From: https://www.spiedigitallibrary.org/conference-proceedings-of-spie on 26 Apr 2023 Terms of Use: https://www.spiedigitallibrary.org/terms-of-use 


\section{ILAS 2015 Sponsors and Supporting Organisations}
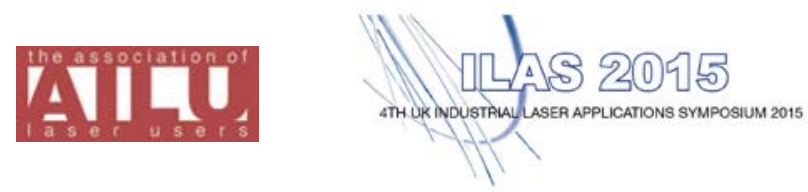

The Association of Industrial Laser Users (AILU), organisers of ILAS 2015, would like to express their sincere appreciation to all the sponsors and organisations mentioned below for their support.
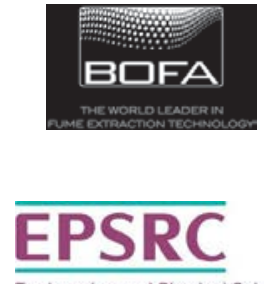

Engineering and Physical Science Research Council

IOP Institute of Physics
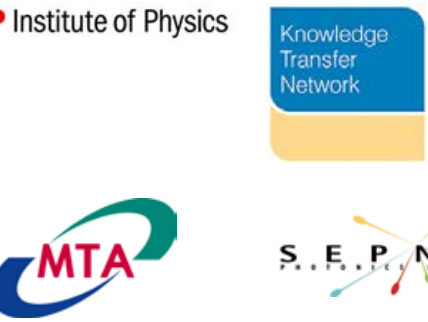
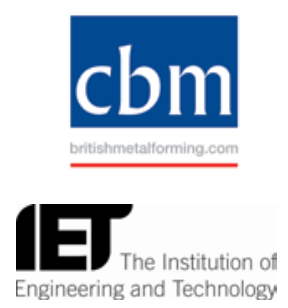

\section{II.}

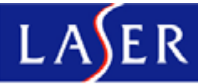

TR A D E R

SPIE.

S. E.P. P. T. T

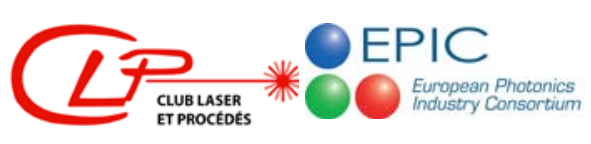

INFAARED
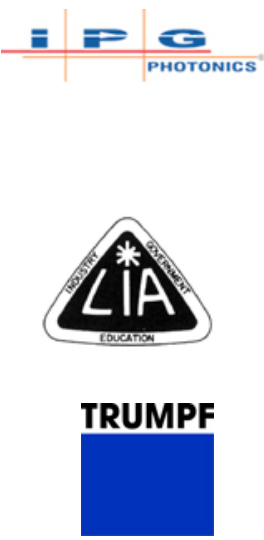
Proc. of SPIE Vol. $9657965701-12$

Downloaded From: https://www.spiedigitallibrary.org/conference-proceedings-of-spie on 26 Apr 2023 Terms of Use: https://www.spiedigitallibrary.org/terms-of-use 